\title{
教育講演 5
}

\section{膠原病に打ける免疫抑制薬の適応と限界}

\author{
順天堂大学膠原病内科
}

橋本 博 史

膠原病に含まれる疾患は自己免疫異常を基盤とする全身性の炎症性疾患の概念で捉えられる，そして，その治 療の基本的考えには免疫異常の是正と抗炎症がある.これらの治療手段には, 非ステロイド抗炎症薬, ステロイ ド薬, 抗リウマチ薬, 免疫抑制薬などがあげられる。この中で, 免疫抑制薬は, 通常, 主たる治療楽が不応性の 場合や主たる治療薬が重篤な副作用のために使用できない場合，ステロイド薬の減量を図る場合，などに際し用 いられることが多く，免疫抑制薬が第一選択薬として用いられる疾患・病態は少ない。ここでは，免疫抑制薬が 第一選択薬となりうる疾患・病態を中心にその適応と問題点について述べる.

\section{1. 翏原病に用いられる免疫抑制薬}

噖原病に用いられる兔疫抑制薬は, プリン拮抗剤のアザチオプリン (AZ), アルキル化剤のシクロフォスファ ミド (CP), 葉酸拮抗剤のメトトレキサート (MTX), プリン合成阻害薬のミゾリビン (MZR), 細胞内伝達物 質阻害菜のシクロスポリン（CSA）などである。これらの中で医療保険適応薬剤は，慢性関節リウマチ（RA） におけるMZR とMTX, ループス腎炎における MZRである。但し，RAにおけるMTXの使用は他の抗りウ マチ薬の効果が不十分の場合に限られる.MZRはMTX, CP, CSAに比べ副作用は少ないが効果も弱い. 従 って, 軽症例や維持療法として適応されることが多い. 医療保険適応外であっても上記の免疫抑制薬の中でその .有用性が指摘されているのは，活動性ループス腎炎ないし汧漫性増殖性ループス腎炎におけるCPの間欠大量静 注療法 (IVCP) ウェゲナー肉芽腫症（WG）におけるCP とステロイドの併用療法で，その他，顕微鏡的多発 血管炎におけるCP とステロイド併用療法，間質性肺炎を伴う多発性筋炎・皮度筋炎に対する CSA が有望視され ている.

\section{2. 免疫抑制薬の適応と限界}

1) RAにおける MTX 少量間欠投与

RA では, MTX の少量間欠投与 (5-20 mg/週) により短期投与, 長期投与いずれにおいても有効性が確認さ れている. 比較的早期より抗炎症効果が認められ，骨破壊の進展防止も示唆されている．また，他の抗りウマチ 薬と比較し投与継続率が高く，エスケーブ現象も少ない. 本邦では保険適応に採用されてから日が浅いが, 活動 期の RA に適応される．不応性ないし効果減弱が認められても増量により効果がみられることがある．また，多 剤併用療法では選択肢の一つに選ばれることが多い.しかしながら重篤な副作用もみられ定期的なモニタリング が必要である。

2）活動性ループス腎炎に対するCP 療法

これまでのループス堅炎に対する免疫抑制薬の対照比較試験による結果を要約すると，長期寛解に対してはス テロイド薬単独よりも免疫抑制薬との併用が有用であること, 免疫抑制薬の中では, AZや MZR は CPよりも 副作用が少なく, 少なからず効果のみられる症例も存在するが, 効果の点では CP の方が優れていること, 特に IVCP は経口投与に比べ副作用が少ないこと，などがあげられる，しかしながら，IVCPは必ずしもすべての症 例に効果がみられるわけではない. 組織学的に活動性病変をみる症例には効果が期待されるが, 非活動性で硬化 性病変をみる症例では効果は期待され難い。むしろ, 慢性化指数を悪化させる可能性があるので留意する. 
3）WGに対するCP とステロイド併用療法

WG では，ステロイド単独投与よりもステロイドと CP の併用療法により生命予後の改善をみる. 特に, 上気 道病変をみる早期のWG に対して効果的とされ，長期寛解導入につながる. しかしながら，少なからず再燃が 認められ，また感染症を含む副作用のリスクは免れない. 副作用軽減の目的で IVCP も試みられるが, 効果の点 で経口投与に比べ優れているとするエビデンスはない。.また, 維持療法に際しては CP の代わりに AZゃ MTX が用いられることがある．末期腎不全に対しては効果は期待できない．結節性多発動脈炎や顕微鏡的多発血管炎 に対してもWG と同様の効果が期待できる.

4）間質性肺炎を伴う PM/DM に対する CSA 療法

PM/DM にみられる間質性肺炎, 特に amyopathicDM にみられる急性間質性肺炎は予後不良であるが，ステ ロイド薬とCSA の併用療法の有用性が指摘されている。本邦におけるアンケート調査によれば，PM/DM の急 性間質性肺炎に対するCSA の有効率は $72.2 \%$ で, 軽快率は $55.5 \%$ を示す. 効果は比較的早期にみられ, 急性 期に有用であるが，慢性間質性肺炎に対しても少なからず効果がみられ，試みるべき治療法である。 